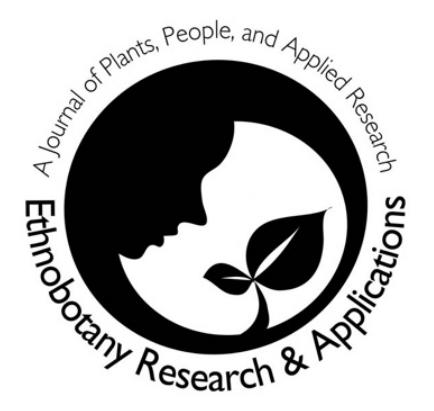

\title{
Ethnobotanical assessment of woody flora of district Kasur (Punjab), Pakistan
}

\author{
Muhammad Waheed, Fahim Arshad, Muhammad Iqbal, \\ Kaniz Fatima and Kaneez Fatima
}

\section{Databases and Inventories}

\begin{abstract}
Background: An ethnobotanical survey of woody flora comprising of trees was conducted from district Kasur, Punjab, Pakistan.
\end{abstract}

Materials and Methods: The data was collected by interviewing native people through a semi-structured questionnaire.

Results: A total of 78 tree plant species belonging to 63 genera and 27 families were explored from the study area. The ethnobotanical results revealed that 21 species had medicinal importance, 11 species were used as fodder, 16 species as fuel wood, 10 species for making agriculture tools, 19 species in furniture, 33 species were ornamentals, fruits or flowers of 7 species were cooked as vegetable, 04 species were utilized as hedge, 6 species for shade purpose and 7 species had multifarious perspectives. The inhabitants of studied area utilized 21 tree species out of 78 against various ailments viz.; cough (33.3\%), asthma (23.8\%), diabetes $(23.8 \%)$, sexual tonics $(28.5 \%)$, liver problems $(9.5 \%)$, skin disorders $(23.8 \%)$, wounds healing $(9.5 \%)$, blood purifier $(9.5 \%)$, kidney problems $(4.7 \%)$, piles $(19 \%)$, digestive disorders $(28.5 \%)$, jaundice $(4.7 \%)$, fever and flu $(28.5 \%)$, menstrual problems $(9.5 \%)$ and toothache $(14.2 \%)$.

Conclusions: The ethnobotanical utilization trend observed was most prevalent amongst the rural communities of the studied area.

Keywords: Ethnobotany, Woody flora, Indigenous knowledge, Kasur.

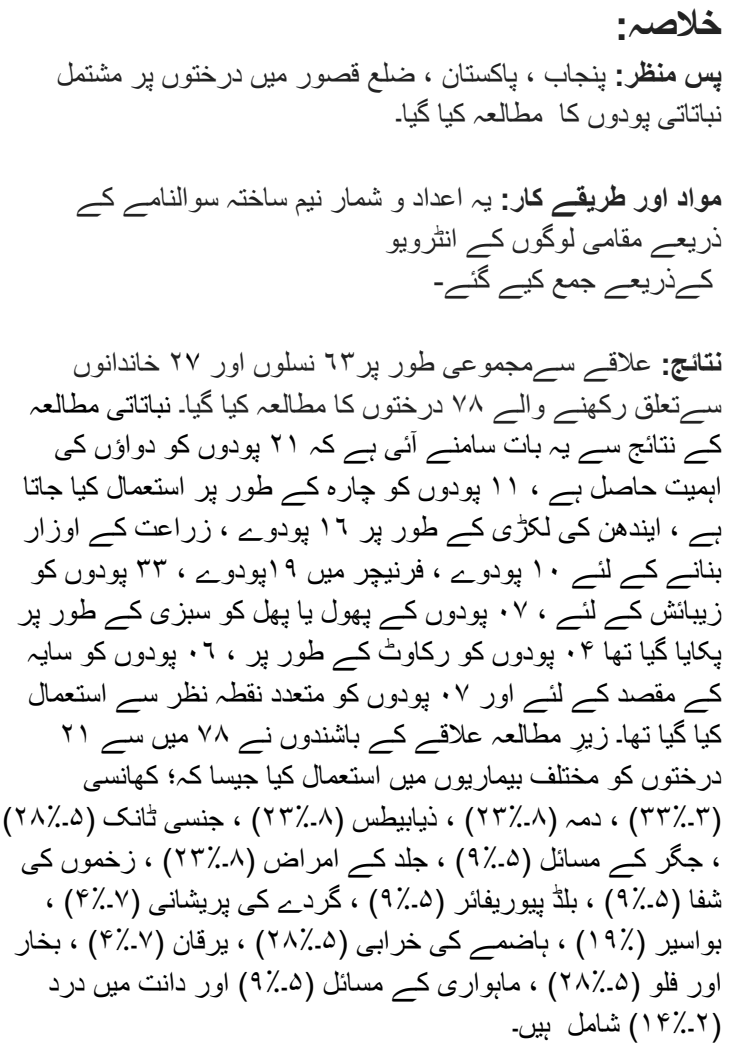

\section{Correspondence}

Muhammad Waheed, Fahim Arshad*, Muhammad Iqbal, Kaniz Fatima and Kaneez Fatima

Department of Botany, University of Okara.

*Corresponding Author: fahim.arshad@uo.edu.pk

Ethnobotany Research \& Applications 20:33 (2020) 


$$
\begin{aligned}
& \text { اخذ شده نتيج: مطالع شده علاقح كى ديبى بر ادريون مين يودون كـ } \\
& \text { استعمال كار رجحان سب سم زئه زياده بايا }
\end{aligned}
$$

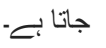

$$
\begin{aligned}
& \text { كليدى الفاظ: ايتهنوبوثنى ، وودّى فلورا، ديسى علم ،قصور }
\end{aligned}
$$

\section{Background}

Plants play an imperative role in humans lives more than animals chiefly due to the collection of different groups of biochemicals with a range of natural actions (Cotton 1996). Plants perform various functions in daily commodities such as they provide shelter, food, medicine, fodder, cosmetics, shadow, fuel, fencing and dyes etc. (Mehwish et al. 2019). Woody flora is important component of every terrestrial ecosystem and plays significant role for the maintenance of ecosystem, water conservation, decreased soil erosion, reduction of severity of floods, avalanches and drought, carbon sequestering and removal of harmful pollutants from the air as well as water resources (Nowak et al. 2007).

Herbal remedies derived from plants have been used for treating various ailments since times antiquities. Despite of rapidly vanishing of traditional knowledge of medicinal and wild edible plants across the world, plants continue to play key role in daily life activities (Pieroni et al. 2014). The relationship between people and plants usually examines the extent of traditional botanical knowledge of the native population and uses such knowledge to exploit plants for a variety of perspectives (Arshad et al. 2014). Traditional knowledge has been essential in developing commercial products and in finding therapeutic remedies. Presently, main focus on ethnobotanical research has been increased considerably in therapeutics, cultural and commercial ethnobotany (Egbe et al. 2012).

Ethnobotanical knowledge on plants and their uses by traditions aboriginal is helpful not only in saving of folk cultures and plants diversity, but also for the health care of people and medicine improvement. Thus modifying the drug made by the local community over a longer period of time may be having an allopathic use (Farnsworth 1993).

The district Kasur (Pakistan) possesses distinctive plant biodiversity that has not been explored before. The reliance of native people of the Kasur district towards the utilization of natural resources as basic commodities of life is an imperative of conducting research in such perspectives. Therefore, the main objective of the study was to evaluate the ethnobotanical information from the local inhabitants, documentation of commercial utilization of woody flora by the aboriginals and assessment of role of woody species in improving the livelihood of people of district Kasur.

\section{Materials and Methods}

District Kasur is 150 to 200 meters above the sea level, located southeast to Lahore at latitude $31^{0} 12$ " $\mathrm{N}$ and longitude $74^{\circ} 44^{\prime \prime} \mathrm{E}$. The total area of district Kasur is $3995 \mathrm{~km}^{2}$ and surrounded by Rivers Sutlej and Ravi (Fig.1).

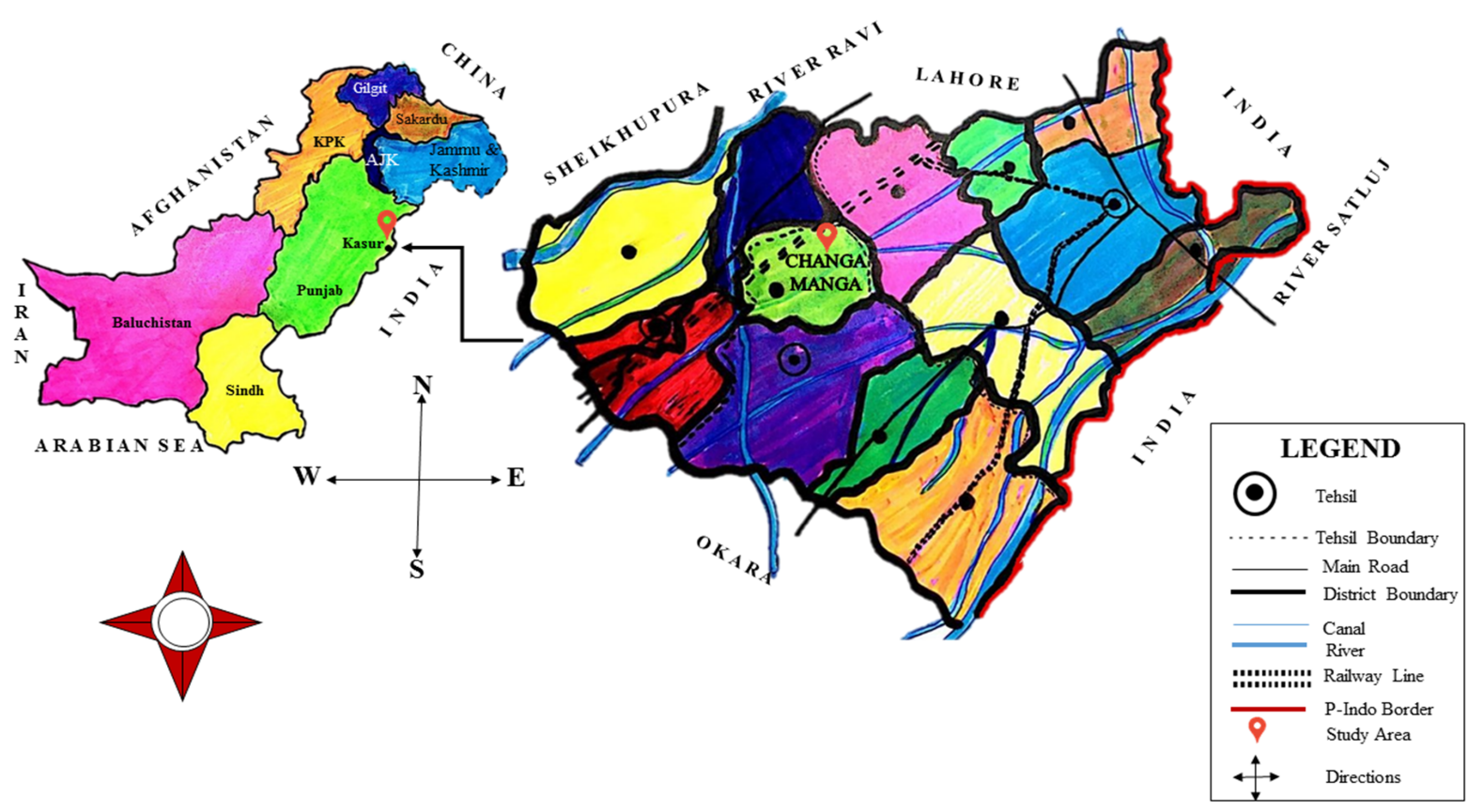

Figure 1. Map of the study area area (District Kasur). 
Field surveys were conducted in district Kasur for the ethnobotanical exploration of trees from 2016-2018. Trees present in parks, along roads, canals, barren lands, housing schemes, agriculture fields, irrigated plantations as well as in government buildings were photographed and identified with the help of flora of Pakistan (Nasir \& Ali 1970-1989, Ali \& Nasir 19901992, Nasir \& Rafiq 1995, Ali \& Qaisar 1992-2010).

Ethnobotanical information was collected by interviewing the local inhabitants of study area through a semi-structured questionnaire. The local informants were belonging to various professions i.e. hakims, merchants, shepherds, nomads, woodcutters, baildaars, teachers, farmers and local healers and of different age groups. A total of 92 informants (77 men and 15 women) were interviewed during the survey. Informants age was ranged from 20 to 95 years old (16 were between 2035 whereas 24 were $36-45$ years old). Most of the informants (45) have more than 50 years age (Table 1).

Ethnobotanical data was also cross checked from already published literature (Ilahi 2008, Abbasi et al. 2010, Ajaib et al. 2010, Qureshi et al. 2011, Khan et al. 2011, Zareen et al. 2013, Kayani et al. 2014, Barkatullah et al. 2015).

Table 1. Demographic information of respondents.

\begin{tabular}{|c|c|c|c|}
\hline Variables & Item & Total & $\%$ \\
\hline \multirow{2}{*}{ Gender } & Men & 77 & 83.70 \\
\hline & Women & 15 & 16.30 \\
\hline \multirow{8}{*}{ Occupation } & Hakims & 20 & 21.74 \\
\hline & Woodcutters & 05 & 5.43 \\
\hline & Shepherds & 06 & 6.52 \\
\hline & Baildaars & 07 & 7.61 \\
\hline & Merchants & 10 & 10.79 \\
\hline & Teachers & 08 & 8.69 \\
\hline & Farmers & 28 & 30.43 \\
\hline & Local healers & 08 & 8.69 \\
\hline \multirow{5}{*}{ Age Group } & $>20$ & 04 & 4.34 \\
\hline & 20 to 35 & 16 & 17.39 \\
\hline & 36 to 50 & 24 & 20.09 \\
\hline & 51 to 65 & 41 & 44.56 \\
\hline & More than 65 & 07 & 7.61 \\
\hline \multirow{5}{*}{$\begin{array}{l}\text { Education } \\
\text { level }\end{array}$} & Illiterate & 15 & 16.30 \\
\hline & Primary & 22 & 23.91 \\
\hline & Middle & 25 & 27.17 \\
\hline & $\begin{array}{l}\text { Higher } \\
\text { secondary }\end{array}$ & 19 & 20.65 \\
\hline & Graduate & 11 & 11.96 \\
\hline
\end{tabular}

\section{Results}

A total of 78 tree species belonging to 63 genera and 27 families were explored from the study area. All species were photographed, identified and their ethnobotanical importance was highlighted (Table 2). The observed arborescent flora was comprised of one monocot family (Araceae), 28 families were dicot and one family was attributed to gymnosperms. The dominant family observed was Fabaceae (21 species), followed by Moraceae (10 species), Meliaceae (5 species each), Bignoniaceae, Euphorbiaceae and Myrtaceae (4 species each), Apocynaceae and Arecaceae (3 species each), Sterculiaceae, Verbenaceae, Sapindaceae, Combretaceae and Boraginaceae included 2 species) each and remaining families had 1 plant species each (Fig. 2).

From the observed woody flora, 21 species had medicinal importance, 11 species were used as fodder, 16 species as fuel wood, 10 species were used for making agriculture tools, 19 species in furniture, 33 species were ornamentals, fruits or flowers of 7 species were cooked as vegetable, 04 species were utilized as hedge, 6 species were grown for shade purpose and 7 species had multifarious perspectives. Ethnomedicinal results of current study revealed that 5 species were used to treat asthma, 7 species for cough, 6 species as sexual tonic, 5 species for skin disorders, 2 species for wounds healing, 5 against diabetes, 2 species as blood purifier, 3 species were utilized in ethnoveterinary medicines, 1 species for kidney problems, 4 species for piles, 5 species for digestive problems, 1 species for jaundice, 6 species for fever and flue, 2 species for liver problems, 2 were used for menstrual disorders and 3 species were utilized for toothache (Fig. 3; Table 2).

\section{Discussion}

Pakistan is blessed with variety of plant diversity due to diversified climate and variety of soil types, the floral diversity is significant economically as well as medicinally (Zareen et al. 2013). People utilize plants in order to cope the daily domestic requirements such as medicines, food, household appliances, livestock fodder, ornamental, fences, housing, agriculture tools, wood, fuel, furniture, religious uses and protecting fields from erosion (Ahmad et al. 2014). The native people of district Kasur utilized 78 species of arborescent (woody) flora for various perspectives viz.; medicinal (16\%), fodders $(8 \%)$, fuel wood $(12 \%)$, agriculture tools $(7 \%)$, furniture $(14 \%)$, ornamentals $(25 \%)$, vegetables $(5 \%)$, hedge $(3 \%)$, shade purpose (5\%) and of multifarious uses (5\%) (Fig. 3). 


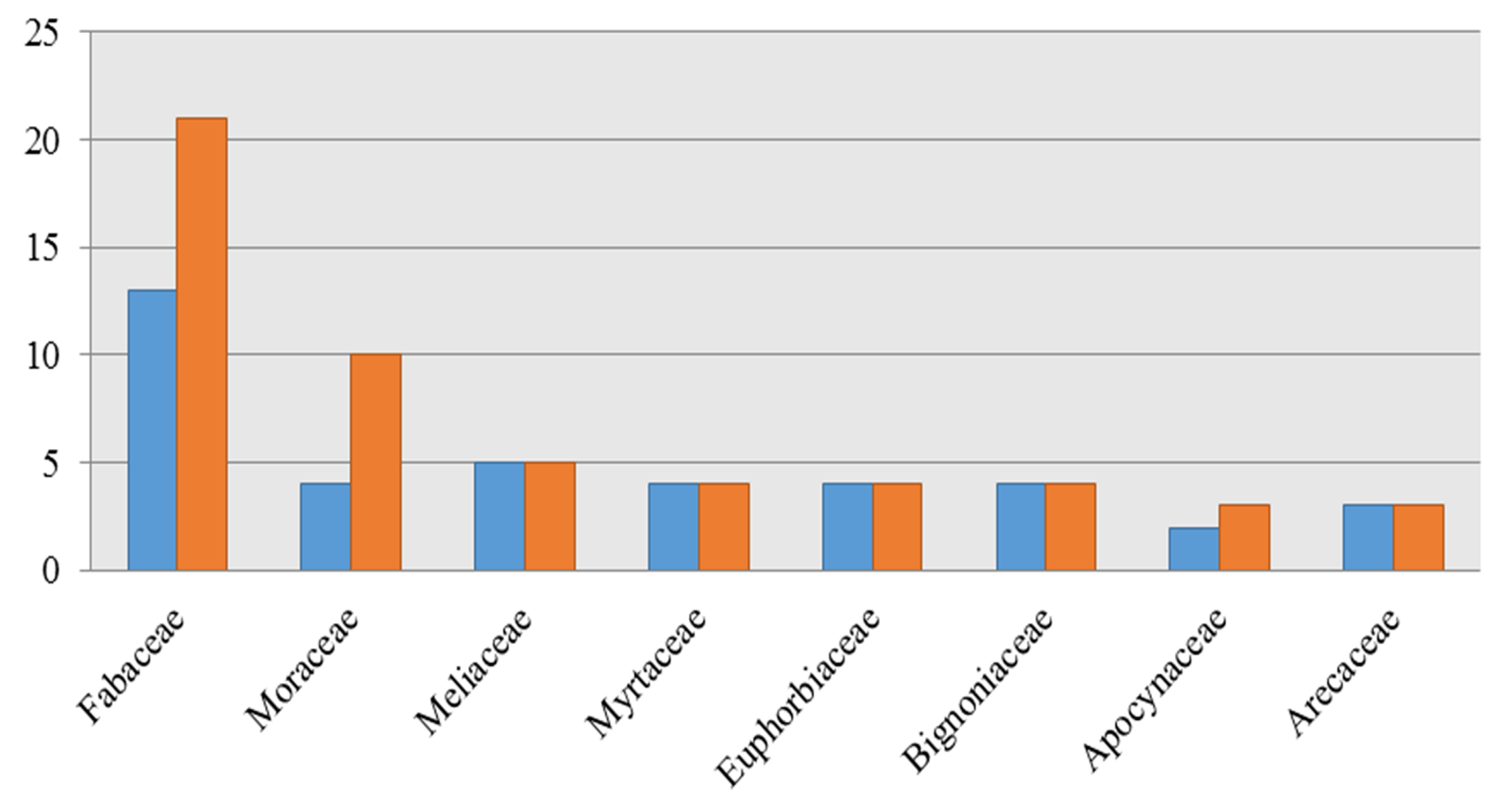

$\square$ No. of Genera $\quad \square$ No. of Species

Figure 2 Distribution of most prevalent families containing genera and species observed from the studied area.

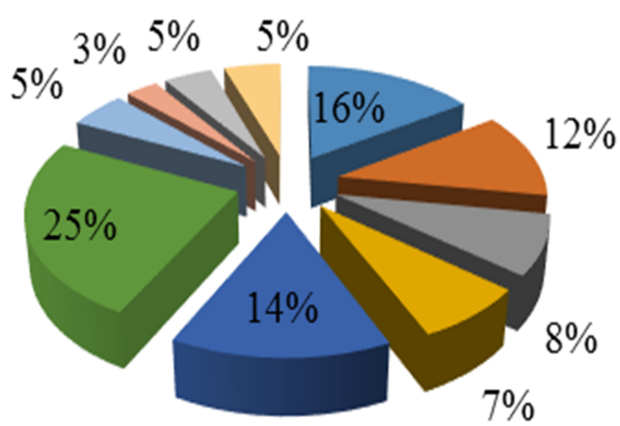

\begin{tabular}{|c|c|c|c|}
\hline Medicinal & Fuel Wood & Fodder & Agriculture Tools \\
\hline Furniture & - Ornamental & Vegetables & Hedge Plants \\
\hline Shade Trees & Multifarious & & \\
\hline
\end{tabular}

Figure 3 Percentage of studied woody flora utilized for various ethnobotanical perspectives.

The people of studied area utilized the fruits of various species i.e., Zizyphus mauritiana, Syzygium cumini, Mangifera indica Morus alba, M. nigra, Ficus palmata and Cordia myxa as reflected from Ibrar et al. (2007), Sher and Al-Yemni (2011), Zareen and Khan (2012) and Abbas et al. (2016). The observed woody flora was widely utilized for making agricultural implements were comprised of Acacia modesta, A. nilotica, Dalbergia sissoo, Capparis decidua and Prosopis cineraria and such studies were also accompanied by Zabihullah et al. (2006), Durrani et al. (2009) and Samreen et al. (2016).
Present study also revealed the usage of tree species viz.; Dalbergia sissoo and Tectona grandis as high-quality timber for furniture industry while Morus alba and M. nigra were widely used for sport goods manufacturing. The wood of Ehreia laevis was first time reported in furniture making from the region as exacerbated from Sher et al. (2011) and Samreen et al. (2016).

People living in remote areas of Kasur district are poor and have less resources to accomplish daily needs. They are generally relying upon local 
vegetation for fuel wood. A total of 16 tress species used as fuel including Acacia farnesiana, $A$. modesta, A. nilotica, Dalbergia sissoo and Ehretia laevis. The local flora has been utilized extensively by the local people because important woody plant species are over-exploited for medicinal, food, coal, timber and other uses. The rural communities mainly depend on livestock for survival, consequently exploited 11 woody species as fodder i.e. Albizzia procera, Broussonetia papyrifera, Melia azedarach Morus alba and $M$. nigra while Prosopis cineraria $P$. juliflora and Zizyphus mauritiana are some promising fodders during scarcities. The use of woody plants as fuel and fodder has also been documented by Durrani et al. (2009), Al-Yemni (2011), Sher et al. (2011) Zareen and Khan (2012) and Samreen et al. (2016).

The knowledge about curing various ailments through utilizing plant resources is very traditional and has been transferred practically and orally from generation to generations (Hassan et al. 2017). The medicinal significance of woody flora by the local inhabitants for curing various ailments was considerably observed (Fig. 4). For instance, bark of Acacia modesta was used for asthma and cough and gum was effective for male sexual dysfunctions while dried pods of Acacia nilotica were employed as folk remedies for kidney pain, male sexual problems and diabetes. Seeds of Acacia indica were utilized against piles and constipation. Leaves and fruits of Eucalyptus camaldulensis and Cordia myxa were effective for headache, cough, flue and jaundice also revealed from the studies of Shah et al. (2015), Ahmad et al. (2019) and Wali et al. (2019).

The studied area was embraced with ethnomedicinally and commercially important plants species. The native people have much ethnobotanical information about plant utilization for treating various ailments. Several important woody plants are endangered due to overexploitation and deforestation. The indigenous people used plants for curing various diseases but despite of Utilizing trees were unfamiliar with proper collection methods. The overall ethnobotanical utilization trends were mostly prevailed amongst the rural communities of the studied area.

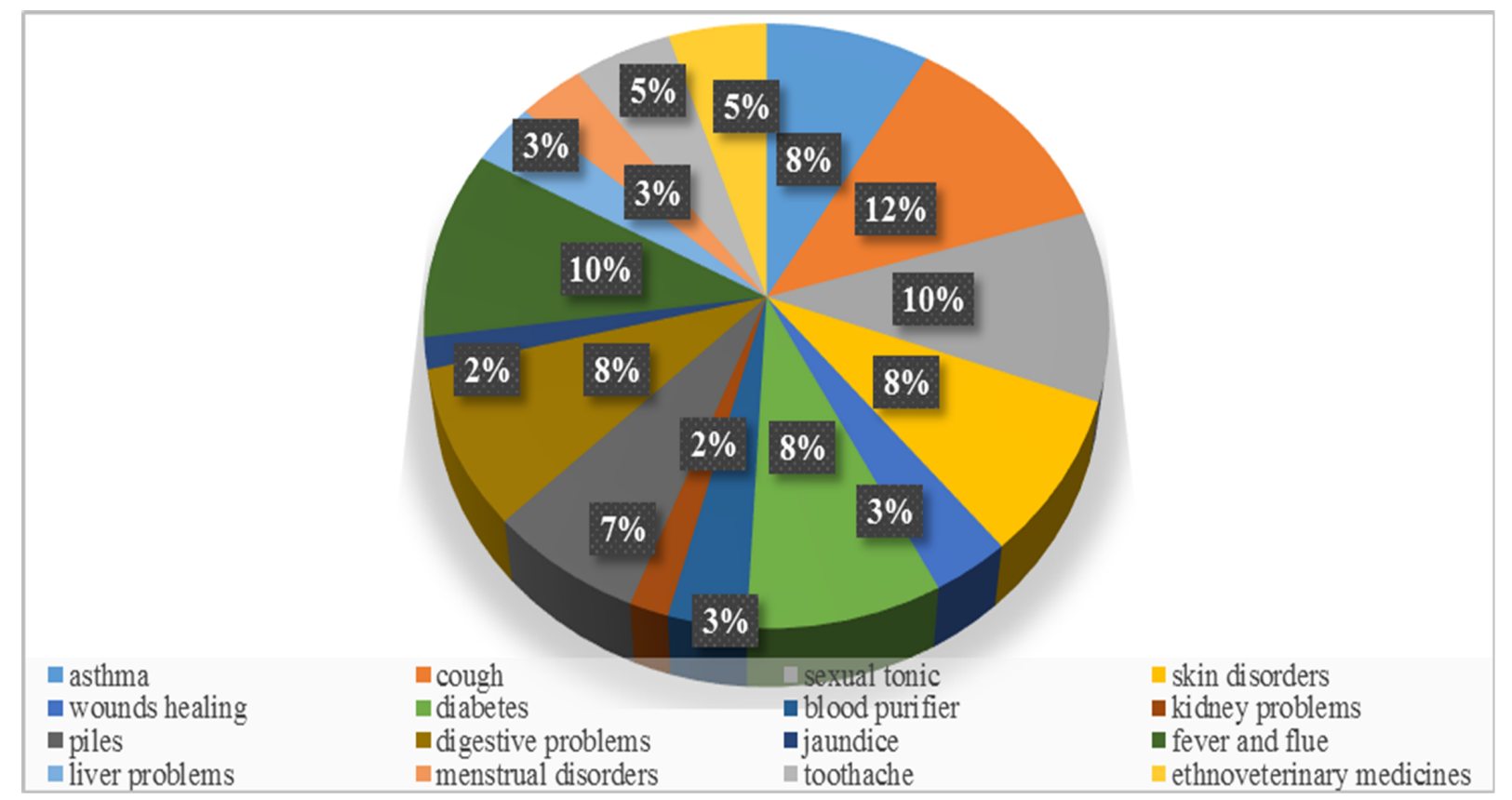

Figure 4. Percentage of studied woody flora utilized for various medicinal perspectives.

\section{Conclusions}

The current ethnobotanical survey provides information about 78 woody species belonging to 29 families, commonly utilized by native inhabitants for various perspectives (medicinal, fodder, fuel wood, agricultural tools, furniture, ornamentals vegetables, hedges, shade trees as well as multifarious uses). Such economic usage was mostly observed amongst the rural communities of the studied area. The woody flora of the district Kasur is disastrously replenishing because of over exploitation of these resources as well as modernization thus decimating the traditional knowledge from the natives of the studied area. It is necessary to conserve such vital knowledge of locals and possible effective strategies should be adopted for the conservation of plant resources. The present paper is an attempt to preserve the traditional knowledge and folk remedies about utilization of woody flora by the local population of District Kasur and adjoining areas. 
Table 2. Ethnobotanical illustrations of observed arborescent flora from the studied area.

\begin{tabular}{|c|c|c|c|c|c|}
\hline Family & Botanical Name & $\begin{array}{l}\text { Common } \\
\text { Name }\end{array}$ & Voucher no. & Locality & Ethnobotanical Uses \\
\hline Anacardiaceae & Mangifera indica L. & Aam & AFK-01 & $\mathrm{KR}, \mathrm{PH}, \mathrm{KP}$. & $\begin{array}{l}\text { Un-ripened fruit is used for making pickle. Fruit is edible. } \\
\text { Wood used in low quality furniture. }\end{array}$ \\
\hline Annonaceae & $\begin{array}{l}\text { Polyalthia longifolia Benth, \& } \\
\text { Hook. f. }\end{array}$ & UltaAshok & AFK-02 & CM, KR, PT. & Ornamental \\
\hline \multirow[t]{3}{*}{ Apocynaceae } & Alstonia scholaris (L.) R. Br. & Shaitan & AFK-03 & KR, CM, PT & $\begin{array}{l}\text { Plant possesses dense branching system that provides a } \\
\text { beautiful landscape thus grown as ornamentals in garden } \\
\text { and avenues. }\end{array}$ \\
\hline & Plumeria obtusa L. & $\begin{array}{l}\text { Gul-a- } \\
\text { Cheen }\end{array}$ & AFK-04 & $\mathrm{CM}, \mathrm{KR}, \mathrm{PT}$ & $\begin{array}{l}\text { Bark is used for joint disorders, while leaves are applied } \\
\text { against asthma. Grown as an ornamental. }\end{array}$ \\
\hline & Plumeria rubraL. & $\begin{array}{l}\text { Gul-a- } \\
\text { Cheen }\end{array}$ & AFK-05 & CM, KR, PT. & $\begin{array}{l}\text { Ornamental; young branches used as miswak for toothache. } \\
\text { Leaves and flowers are also applied for cough, fever, } \\
\text { diarrhoea and piles. }\end{array}$ \\
\hline Arecaceae & $\begin{array}{l}\text { Trachycarpus fortunei } \\
\text { (Hook.) H. Wendl. }\end{array}$ & $\begin{array}{l}\text { Windmill } \\
\text { Palm }\end{array}$ & AFK-06 & CM & Ornamental plant. \\
\hline \multirow[t]{4}{*}{ Bignoniaceae } & $\begin{array}{l}\text { Heterophragma adenophylla } \\
\text { (Wall. ex G. Don) Dop }\end{array}$ & Naag Palli & AFK-07 & $\mathrm{CM}$ & Ornamental, Shade tree. \\
\hline & Jacaranda ovalifolia R. Br. & $\begin{array}{c}\text { Gul e } \\
\text { Neelam }\end{array}$ & AFK-08 & $\mathrm{CM}, \mathrm{KR}$ & Ornamental, Shade tree. \\
\hline & $\begin{array}{l}\text { Kigelia africana (Lam.) } \\
\text { Benth. }\end{array}$ & $\begin{array}{l}\text { Gul-e- } \\
\text { Fanoos }\end{array}$ & AFK-09 & CM & Ornamental, Shade tree. \\
\hline & Oroxylum indicum (L.) Kurz & $\begin{array}{c}\text { Ulti } \\
\text { Talwaar }\end{array}$ & AFK-10 & $\mathrm{CM}$ & Ornamental, Shade tree \\
\hline Bombacaceae & Bombax ceiba L. & Simbal & AFK-11 & $\begin{array}{l}\text { KR, KRK, } \\
\text { PT, CM, RJ, } \\
\text { PH, DS, KK, } \\
\text { KP. }\end{array}$ & $\begin{array}{l}\text { Young roots are used as vegetable and for enhancing sexual } \\
\text { power. Fibers obtained from seed were utilized for stuffing } \\
\text { mattress and pillows. Flowers are usually grazed by cows. } \\
\text { Wood is used in furniture and paper industry. }\end{array}$ \\
\hline \multirow[t]{2}{*}{ Boraginaceae } & Cordia myxa L. & Lasoora & AFK-12 & PT, CM, KR. & $\begin{array}{l}\text { Un-ripened fruit is used for making pickle while ripened fruit } \\
\text { is eaten as it is sweet in taste. Leaves and fruit are utilized } \\
\text { for treating cough, flue and jaundice. Wood is used for } \\
\text { making agricultural tools. }\end{array}$ \\
\hline & Ehretia laevis Roxb. & Gondi & AFK-13 & PT, CM & $\begin{array}{l}\text { Leaves are used as fodder. Fruit is edible. Wood is used as } \\
\text { fuel and for making furniture. }\end{array}$ \\
\hline
\end{tabular}




\begin{tabular}{|c|c|c|c|c|c|}
\hline Capparidaceae & $\begin{array}{l}\text { Cappari. decidua (Forssk.) } \\
\text { Edgew. }\end{array}$ & Karir & AFK-21 & $\mathrm{CH}, \mathrm{KR}, \mathrm{CM}$ & $\begin{array}{l}\text { Plant is effective against diabetes, toothache, asthma and } \\
\text { skin problems. Wood is used for making agriculture tools. } \\
\text { Fruits are used in pickles and utilized by the inhabitants } \\
\text { commonly. }\end{array}$ \\
\hline \multirow[t]{2}{*}{ Combretaceae } & Conocorpus. erectus L. & $\begin{array}{l}\text { Conocarpu } \\
\text { s }\end{array}$ & AFK-22 & $\begin{array}{l}\text { KR, CM, PT. } \\
\text { KRK, PH. }\end{array}$ & $\begin{array}{l}\text { Ornamental. It is grown as hedge plant and to make green } \\
\text { belts along the roads. }\end{array}$ \\
\hline & $\begin{array}{l}\text { Terminalia. arjuna (Roxb. Ex } \\
\text { DC) Wt. \& Arn. }\end{array}$ & Arjun & AFK-23 & $\begin{array}{l}\text { KR, KRK, } \\
\mathrm{PT}, \mathrm{CM}, \mathrm{KP}, \\
\text { KK HB. }\end{array}$ & $\begin{array}{l}\text { Ornamental, Shade tree, Bark of tree used by heart patients. } \\
\text { Leaves are used as fodder for cattle's. }\end{array}$ \\
\hline Dilleniaceae & Dillenia. indica L. & Gul-e-Mast & AFK-24 & KR. CM & Ornamental. \\
\hline Ebenaceae & $\begin{array}{l}\text { Diospyros. embrdyopteris } \\
\text { Pers. }\end{array}$ & Gaab & AFK-25 & $\mathrm{CM}$ & Ornamental, shade tree. Fruits are sometimes eaten. \\
\hline \multirow[t]{4}{*}{ Euphorbiaceae } & Bischofia javanica Blume & $\begin{array}{l}\text { Bishop } \\
\text { Tree }\end{array}$ & AFK-26 & $\mathrm{CM}$ & Ornamental, Important as an Avenue plant \\
\hline & Phyllanthus emblica L. & Amla & AFK-27 & $\begin{array}{l}\text { CM, PT, KR, } \\
\text { KRK. }\end{array}$ & Ornamental. Fruits are also utilized in pickles. \\
\hline & $\begin{array}{l}\text { Putranjiva roxburghii (Wall.) } \\
\text { Hurusawa }\end{array}$ & Pata Jan & AFK-28 & $\mathrm{CM}$ & Ornamental, Shade tree. \\
\hline & Ricinus communis L. & Arind & AFK-29 & $\begin{array}{l}\text { KR, KRK, } \\
\mathrm{PT}, \mathrm{CM}, \mathrm{RJ}, \\
\mathrm{PH}, \mathrm{KK}, \mathrm{KP}, \\
\mathrm{CH}, \mathrm{RJ}, \mathrm{HB}\end{array}$ & $\begin{array}{l}\text { Decoction of fruit and stem is applied against rheumatic and } \\
\text { arthritis. Seeds are used against scorpion bite. Leaves are } \\
\text { utilized for wound healing and swelling. Paste of root is used } \\
\text { for the treatment of piles. Castor oil of plant seeds is } \\
\text { purgative in nature. Seed oil is also applied for paralysis and } \\
\text { used as muscle tonic. }\end{array}$ \\
\hline \multirow[t]{3}{*}{ Fabaceae } & Acacia farnesiana (L.) Wild & $\begin{array}{l}\text { Boo Wala } \\
\text { Kikar }\end{array}$ & AFK-36 & $\mathrm{CM}, \mathrm{PT}$ & $\begin{array}{l}\text { Plant is a source of gum. Leaves are used as fodder for goats } \\
\text { and cows. Branches are supporting the stem of Momordica } \\
\text { (a climber crop). Stem/branches are used as fuel wood. }\end{array}$ \\
\hline & Acacia modesta Wall & Phulai & AFK-37 & $\mathrm{KP}, \mathrm{CM}, \mathrm{PT}$ & $\begin{array}{l}\text { Bark of the stem is utilized for curing asthma, cough and } \\
\text { dysentery. Gum of the plant is used for enhancing sexual } \\
\text { power. Twigs are usually taken as miswak for cleaning teeth. } \\
\text { Wood is used for making agriculture tools and as fuel wood. }\end{array}$ \\
\hline & Acacia nilotica (L.) Delile. & $\begin{array}{c}\text { Babool/ } \\
\text { Desi Kiker }\end{array}$ & AFK-38 & $\begin{array}{l}\text { KR. CM, PT, } \\
\text { KP, CH, RJ, } \\
\text { KRK }\end{array}$ & $\begin{array}{l}\text { Bark of the stem is effective against foot and mouth diseases } \\
\text { in cattle. Bark is used for preparing alcohol drink and for } \\
\text { tanning leather. Dried pods and bark are the best remedies } \\
\text { against kidney pain, diabetes and sexual disorders. Wood is } \\
\text { used for making furniture, agriculture tools and fuel. }\end{array}$ \\
\hline
\end{tabular}




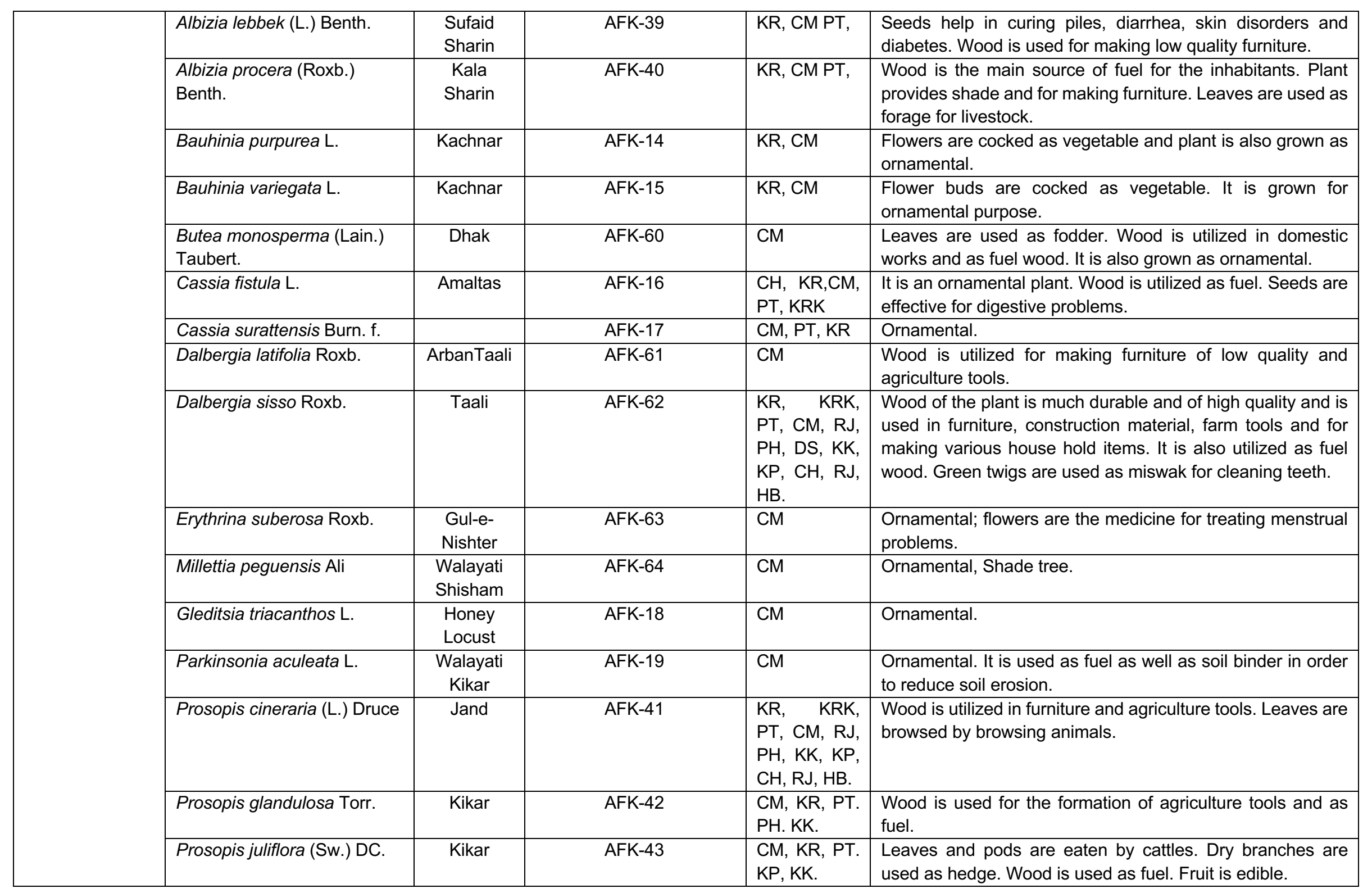




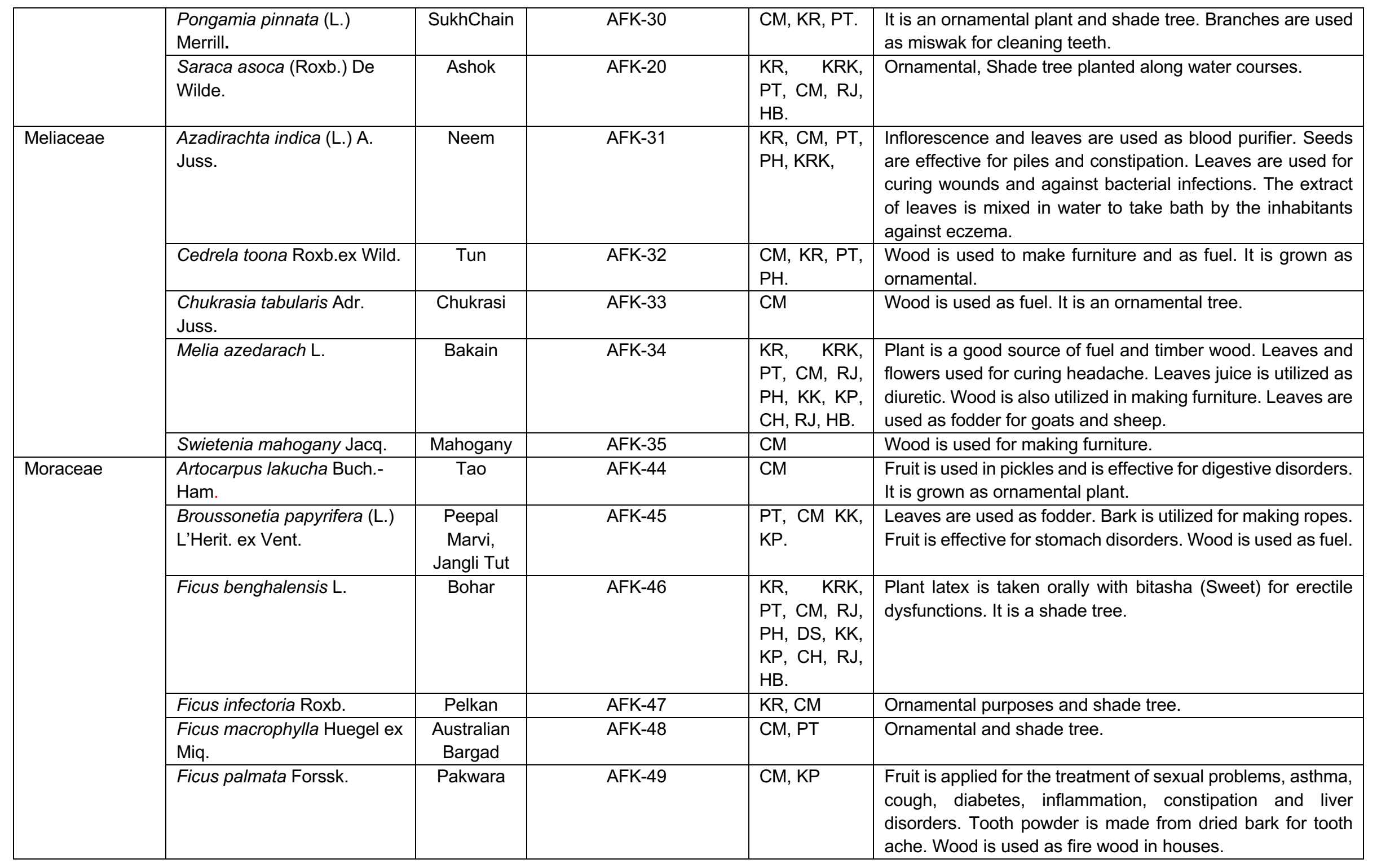




\begin{tabular}{|c|c|c|c|c|c|}
\hline & Ficus racemosa $\mathrm{L}$. & Gulhar & AFK-50 & $\mathrm{CM}, \mathrm{KR}, \mathrm{PH}$. & $\begin{array}{l}\text { Mainly planted along roadsides as shade tree. Fruit is edible } \\
\text { and applied for curing eyes problems. }\end{array}$ \\
\hline & Ficus religiosa L. & Peepal & AFK-51 & $\begin{array}{l}\text { KR, KRK, } \\
\text { PT, CM, RJ, } \\
\text { PH, KK, KP, } \\
\text { CH, RJ, HB. }\end{array}$ & $\begin{array}{l}\text { Extract from bark is used for regulating women menstrual } \\
\text { cycle. Bark is also utilized for the treatment of fever, flue and } \\
\text { liver disorders. Plant has large leaves size and canopy and } \\
\text { used as shade tree in villages. }\end{array}$ \\
\hline & Morus alba L. & Tot Sufaid & AFK-52 & $\begin{array}{l}\text { KR, KRK, } \\
\text { PT, CM, RJ, } \\
\text { PH, KK, KP, } \\
\text { CH, RJ, HB. }\end{array}$ & $\begin{array}{l}\text { Fruit is a tonic for chest pain, sexual problems and heart } \\
\text { diseases. Wood is utilized in manufacturing of sports goods } \\
\text { and furniture. Fresh branches are used for making baskets } \\
\text { for agriculture purposes. Leaves are used as fodder for } \\
\text { cattle. Leaves are also fed to silkworm for silk production. } \\
\text { Wood is utilized for fuel purposes. }\end{array}$ \\
\hline & Morus nigra L. & Tot Siah & AFK-53 & $\begin{array}{l}\text { KR, KRK, } \\
\text { PT, CM, RJ, } \\
\text { PH, KK, KP, } \\
\text { CH, RJ, HB. }\end{array}$ & $\begin{array}{l}\text { Fruit is eaten by human. Fruit is also used as tonic for cough, } \\
\text { and throat ailments and has cooling effects. Leaves are } \\
\text { eaten by animals. Wood is used in furniture and sports } \\
\text { goods. Fresh branches are used for making baskets for } \\
\text { farmers. Wood is good source of fuel. Leaves of plant are } \\
\text { utilized for rearing silk worms. }\end{array}$ \\
\hline \multirow[t]{4}{*}{ Myrtaceae } & $\begin{array}{l}\text { Callistemon lanceolatus } \\
\text { (Sm.) Sweet. }\end{array}$ & $\begin{array}{l}\text { Bottle } \\
\text { Brush }\end{array}$ & AFK-54 & $\begin{array}{l}\text { KR, PT, CM, } \\
\text { RJ, PH, DS, } \\
\text { KK, } \quad \text { KP, } \\
\text { KRK. }\end{array}$ & Ornamental, As an Avenue plant due to its floral beauty. \\
\hline & $\begin{array}{l}\text { Eucalyptus camaldulensis } \\
\text { Dehnh. }\end{array}$ & Sufaida & AFK-55 & $\begin{array}{l}\text { KR, KRK, } \\
\text { PT, CM, RJ, } \\
\text { PH, DS, KK, } \\
\text { KP, CH, RJ, } \\
\text { HB. }\end{array}$ & $\begin{array}{l}\text { Leaves are applied in headache and flue. Wood is utilized in } \\
\text { making furniture of low quality and as fuel. Twigs are used } \\
\text { as miswak. }\end{array}$ \\
\hline & Psidium guajava L. & Amrod & AFK-56 & $\begin{array}{l}\text { KR, KRK, } \\
\text { PT, CM, RJ, } \\
\text { PH, KK, KP, } \\
\text { CH, RJ, HB. }\end{array}$ & $\begin{array}{l}\text { Leaves are effective against cough and common cold. Wood } \\
\text { is used as fuel. }\end{array}$ \\
\hline & Syzygium cumini (L.) Skeels & Jaman & AFK-57 & $\begin{array}{l}\text { KR, KRK, } \\
\text { PT, CM, RJ, } \\
\text { PH, KK, KP, } \\
\text { CH, RJ, HB. }\end{array}$ & $\begin{array}{l}\text { Fruit is edible and also useful for diabetic patients. Leaves } \\
\text { are used for curing cough and flu. }\end{array}$ \\
\hline Palmae & $\begin{array}{l}\text { Livistona chinensis (Jacq.) } \\
\text { R. Br. ex Mart. }\end{array}$ & Wall Palm & AFK-58 & $\begin{array}{l}\text { PT, CM, CH, } \\
\text { KR }\end{array}$ & Ornamental, Shade tree. \\
\hline
\end{tabular}




\begin{tabular}{|c|c|c|c|c|c|}
\hline & $\begin{array}{l}\text { Roystone aregia (Kunth) } \\
\text { O.F. Cook. }\end{array}$ & $\begin{array}{l}\text { Royal } \\
\text { Palm, } \\
\text { Bottle } \\
\text { Palm }\end{array}$ & AFK-59 & $\mathrm{CM}, \mathrm{KR}$ & Ornamental \\
\hline Pinaceae & Pinus roxburghii Sargent & Chir & AFK-65 & $\mathrm{CM}$ & Ornamental, Shade tree. \\
\hline Proteaceae & $\begin{array}{l}\text { Grevillea robusta A. Cunn. } \\
\text { ex } \mathrm{R} \text {. Br. }\end{array}$ & $\begin{array}{l}\text { Shah } \\
\text { Baloot }\end{array}$ & AFK-66 & $\mathrm{CM}$ & Ornamental. \\
\hline Rhamnaceae & Ziziphus mauritiana Lamk. & Ber & AFK-67 & $\begin{array}{l}\text { KR, KRK, } \\
\text { PT, CM, RJ, } \\
\text { HB. }\end{array}$ & $\begin{array}{l}\text { Fruits are edible, leaves are eaten by goats, wood is used for } \\
\text { making agriculture tools and as fuel. }\end{array}$ \\
\hline Rutaceae & Poncirus trifoliate (L.) Raf. & Khatti & AFK-68 & CM, KR, PT. & $\begin{array}{l}\text { Plant is grown as hedge around the parks and gardens. Fruit } \\
\text { is edible as pickle and is useful for skin problems. }\end{array}$ \\
\hline \multirow[t]{2}{*}{ Salicaceae } & Populus nigra L. & Poplar & AFK-69 & $\begin{array}{l}\text { CM, KR, PT. } \\
\mathrm{PH} .\end{array}$ & Leaves are used as fodder. Wood is used as fuel. \\
\hline & Salix tetrasperma Roxb. & Bilo & AFK-70 & $\mathrm{CM}$ & Branches are used for making baskets. Wood is used as fuel. \\
\hline \multirow[t]{2}{*}{ Sapindaceae } & Sapindus mukorossi Gaertn. & Reetha & AFK-71 & $\mathrm{CM}$ & $\begin{array}{l}\text { Ornamental, Shade tree. Fruit is used for cleaning hair and } \\
\text { skin. }\end{array}$ \\
\hline & Schleicuera trijuga Wild. & $\begin{array}{l}\text { Jangli } \\
\text { Leechi }\end{array}$ & AFK-72 & $\mathrm{CM}$ & $\begin{array}{l}\text { Fruit is edible and used as prickle. An ornamental, Shade } \\
\text { tree. }\end{array}$ \\
\hline Sapotaceae & Mimusops elengi L. & Molsiri & AFK-73 & $\mathrm{CM}$ & Ornamental, Shade tree. \\
\hline \multirow[t]{2}{*}{ Sterculiaceae } & $\begin{array}{l}\text { Pterospermum acerifolium } \\
\text { (L.) Willd. }\end{array}$ & $\begin{array}{c}\text { Kanak } \\
\text { Champa }\end{array}$ & AFK-74 & $\mathrm{CM}$ & Ornamental, Shade tree. Flowers are used for stomach ulcer. \\
\hline & Sterculia villosa Roxb. & $\begin{array}{c}\text { Masso } \\
\text { (Sterculia) }\end{array}$ & AFK-75 & $\mathrm{CM}$ & Ornamental, Shade tree. \\
\hline Tamaricaceae & $\begin{array}{l}\text { Tamarix aphylla (Linn.) } \\
\text { Karst. }\end{array}$ & Frash & AFK-76 & $\begin{array}{l}\text { KR, KRK, } \\
\text { PT, CM, RJ, } \\
\text { HB. }\end{array}$ & $\begin{array}{l}\text { Leaves are used for making clay oven. Wood is used for } \\
\text { furniture making and as fuel. }\end{array}$ \\
\hline \multirow[t]{2}{*}{ Verbenaceae } & $\begin{array}{l}\text { Gmelina arborea Roxb. ex } \\
\text { Sm. }\end{array}$ & Candahar & AFK-77 & $\mathrm{CM}$ & Ornamental. \\
\hline & Tectona grandis L. f. & Sagwan & AFK-78 & $\mathrm{CM}$ & $\begin{array}{l}\text { Ornamental, Shade and timber tree mainly used by the } \\
\text { natives for crafting high class furniture. }\end{array}$ \\
\hline
\end{tabular}

Legend: $\mathrm{CM}=$ Changa Manga, $\mathrm{KR}=$ Kasur, $\mathrm{PT}=$ Pattoki, RJ=Raja Jang, KRK=Kot Radha Kishan, $\mathrm{HB}=$ Habibabad, $\mathrm{KK}=\mathrm{Khudian}$ Khas, $\mathrm{KP}=\mathrm{Kangun} \mathrm{Pur}, \mathrm{CH}=\mathrm{Chunian}, \mathrm{PH}=\mathrm{Pholnagar}$, DS=Deosial. 


\section{Declarations}

List of Abbreviations: Fig=Figure, $\mathrm{CM}=$ Changa

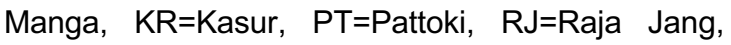
$\mathrm{KRK}=\mathrm{Kot}$ Radha Kishan, $\mathrm{HB}=$ Habibabad, $\mathrm{KK}=$ Khudian Khas, $\mathrm{KP}=$ Kangun Pur, $\mathrm{CH}=$ Chunian, $\mathrm{PH}=$ Pholnagar, DS=Deosial

Ethics Approval and Consent to Participate: Study was approved by the Rules of Okian Botanical Society; Department of Botany, University of Okara. All work was done under the requirements of Nagoya Protocol on Access to Genetic Resources and the Fair and Equitable Sharing of Benefits Arising from their Utilization to the Convention on Biological Diversity.

Consent for Publication: Not Applicable

Availability of Data and Materials: All the raw data is available from authors other than personal information of participants.

Competing Interests: There are no competing interests.

Funding: The study was a non-funded research.

Authors' Contributions: FA substantially concepted project design and supervised the entire research. MW and Kaniz F carried out extensive field work for acquisition of the data and specimens for herbarium. FA, MW drafted the manuscript, Kaneez $\mathrm{F}$ added the supplementary figures and Maps. MI critically reviewed and helped in compilation of research. Kaneez $F$ helped formatting the article according to publishing requirements. All authors interpreted and analyzed the data.

\section{Literature Cited}

Abbasi AM, Khan MA, Ahmad M, Qureshi R, Arshad M, Jahan S, Zafar M, Sultana S. 2010. Ethnobotanical study of wound healing herbs among the tribal communities in Northern Himalaya Ranges District Abbottabad, Pakistan Journal of Botany 42(6): 2777-2782.

Ahmed N, Anees M and Zhang L. 2019. An appraisal of ethnobotanical investigation of indigenous flora from a high temperature affected area in the Southern Punjab, Pakistan. Pakistan Journal of Botany 51-4(32).

Ajaib M, Khan Z, Khan N, Wahab M. 2010. Ethnobotanical studies on useful shrubs of District Kotli, Azad Jammu \& Kashmir,Pakistan. Pakistan Journal of Botany 42(3): 1407-1415.

Ali SI, Nasir YJ. 1990-92. Flora of Pakistan. Department of Botany, University of Karachi and National Herbarium, PARC, Islamabad, Pakistan.

Ali SI, Qaisar M. 1992-2010. Flora of Pakistan. Department of Botany, University of Karachi and National Herbarium, PARC, Islamabad, Pakistan.

Arshad M, Ahmad M, Ahmed E, Saboor A, Abbas A, Sadiq S. 2014. An ethnobiological study in Kala
Chitta hills of Pothwar region, Pakistan: multinomial logit specification. Journal of ethnobiology and ethnomedicine10(1):13

Barkatullah, Ibrar M, Rauf A, Hadda TB, Mubarak MS, Patel S. 2015. Quantitative ethnobotanical survey of medicinal flora thriving in Malakand Pass Hills, Khyber Pakhtunkhwa, Pakistan Journal of Ethnopharmacology 169: 335-346.

Cotton, CM. 1996. Ethnobotany: Principles and Applications. John Wiley and Sons Ltd., Chichister, England.

Durrani MJ, Manzoor M, Irfan S. 2009. Folk uses of some plants of Quetta, Pakistan. Pakistan Journal Plant Sciences15(1): 1-9.

Egbe EA, Tabot PT, Fonge BA. 2012. Ethnobotany and prioritization of some selected tree species in South-western Cameroon. Ethnobotany Research and Applications 10:235-246.

Farnsworth NR. 1993. Ethnopharmacology and future drug development: The North American experience. Journal of Ethnopharmacology 38(2-3): 137-143.

Hassan N, Wang D, Shuaib M, Zhong Z, Nisar M, Ahmad W, Ahmed S, Khan A. 2017. Identification and ethnobotanical survey of profitable medicinal plants used as remedy in Sangina Pakistan. International Journal of Herbal Medicine 5(4): 117123.

Ibrar M, Hussain F, Sultan A. 2007. Ethnobotanical studies on plant resources of Ranyal Hills, District Shangla, Pakistan. Pakistan Journal of Botany 39(2): 329-337.

Ilahi I. 2008. Ethnobotanical problems associated with the regeneration of herbals in the Kohat Region. Pakistan Journal of Botany 40(4): 1743-1753.

Kayani S, Ahmad M, Zafar M, Sultana S, Khan MPZ, Ashraf MA, Yaseen G. 2014. Ethnobotanical uses of medicinal plants for respiratory disorders among the inhabitants of Gallies-Abbottabad, Northern Pakistan. Journal of Ethnopharmacology 156: 47-60.

Khan B, Abdukadir A, Qureshi RA, Mustafa G. 2011. Medicinal uses of plants by the inhabitants of Khunjerab National Park, Gilgit, Pakistan. Pakistan Journal of Botany 43(5): 2301-2310.

Mehwish M, Ajaib M, Bhatti KH, Ishtiaq M, Humaira K, Tanveer H, Ghani A, Waheeda M. 2019. An inventory of traditional knowledge of wild plants of Watala National Park and allied villages from Bhimber District, Azad Jammu and Kashmir, Pakistan. Applied Ecology and Environmental Research 17(5):12023-12055.

Nasir E, Ali SI. 1970- 1989. Flora of Pakistan. National Herbarium, PARC, Islamabad and Department of Botany, University of Karachi, Karachi, Pakistan. 
Nasir YJ, Rafiq AR. 1995. Wild flowers of Pakistan. Oxford University Press, Karachi, Pakistan.

Nowak DJ, Hoehn R, Crane DE. 2007. Oxygen production by urban trees in United States. Arboriculture and Urban Forestry 33(3):220-226.

Qureshi R, Maqsood M, Arshad M, Chaudhry AK. 2011. Ethnomedicinal uses of plants by the people of Kadhi areas of Khushab, Punjab, Pakistan. Pakistan Journal of Botany 43(1): 121-133.

Pieroni A, Nedelcheva A, Dogan Y. 2014 Local knowledge of medicinal plants and wild food plants among Tatars and Romanians in Dobruja (SouthEast Romania), Genetic Resources and Crop Evolution, 62:605-20.

Shah A, Rahim S, Bhatti KH, Khan A, Din N, Imran $M$, Mohsin M, Ishtiaq M, Nabila A, Ansari A, Hussain S, Zafar M, Mushtaq M, Mumtaz E, Iqbal J. 2015. Ethnobotanical study and conservation status of trees in the district Sargodha, Punjab, Pakistan. Pyton, International Journal of Experimental Botany 84: 34-44.

Sher H, Al-Yemeni M. 2011. Economically and ecologically important plant communities in High Altitude Coniferous Forest of Malam Jabba, Swat, Pakistan. Saudi Journal of Biological Sciences 18(1): 53-61.

Sher H, Elyemeni M, Hussain K, Sher H. 2011. Ethnobotanical and economic observations of some plant resources from the northern parts of Pakistan. Ethnobotany Research and Applications 9:027-041.

Wali R, Rahman K, Raja NI, Qureshi R, Bussmann RW, Mashwani Z. 2019. A quantitative medicobotanical expedition of Fairy Meadows National Park, Diamir, Gilgit Baltistan, Pakistan. Ethnobotany Research and Applications 18:35.

Zabihullah Q, Rashid A, Akhtar N. 2006. Ethnobotanical survey of Kot Manzary Baba Valley, Malakand Agency, Pakistan. Pakistan Journal of Plant Sciences 12: 115-122.

Zereen A, Khan Z, Ajaib M. 2013. Ethnobotanical evaluation of the shrubs of Central Punjab, Pakistan. Bangladesh Journal of Plant Taxonomy 20(1): 67-76.

Zereen A, Khan Z. 2012. A survey of ethnobotanically important trees of Central Punjab, Pakistan. Biologia (Pakistan) 58 (1\&2), 21-30. 